\title{
Encapsulated Escherichia coli in alginate beads capable of secreting a heterologous pectin lyase Rigini M Papi ${ }^{1}$, Sotiria A Chaitidou ${ }^{1}$, Fotini A Trikka ${ }^{1}$ and Dimitrios A Kyriakidis*1,2
}

\begin{abstract}
Address: ${ }^{1}$ Laboratory of Biochemistry, Department of Chemistry, Aristotle University of Thessaloniki, Thessaloniki, 54124, Greece and ${ }^{2}$ National Hellenic Research Foundation, 48 Vasileos Konstantinou Ave., 11635 Athens, Greece

Email: Rigini M Papi - rigini@chem.auth.gr; Sotiria A Chaitidou - schait@cperi.certh.gr; Fotini A Trikka - ftrik@physics.auth.gr; Dimitrios A Kyriakidis* - kyr@chem.auth.gr

* Corresponding author
\end{abstract}

Published: I4 December 2005

Microbial Cell Factories 2005, 4:35
Received: 19 October 2005

Accepted: 14 December 2005

article is available from: http://www.microbialcellfactories.com/content/4/I/35

(c) 2005 Papi et al; licensee BioMed Central Ltd.

This is an Open Access article distributed under the terms of the Creative Commons Attribution License (http://creativecommons.org/licenses/by/2.0), which permits unrestricted use, distribution, and reproduction in any medium, provided the original work is properly cited.

\begin{abstract}
Background: Production of heterologous proteins in the E. coli periplasm, or into the extracellular fluid has many advantages; therefore naturally occurring signal peptides are selected for proteins translocation. The aim of this study was the production in high yields of a recombinant pectin lyase that is efficiently secreted and the encapsulation of transformed $E$. coli cells for pectin degradation in a biotechnological process.
\end{abstract}

Results: The nucleotide sequence of Bacillus subtilis $\alpha$-amylase's signal peptide was fused to the $\mathrm{N}$ terminal of an heterologously expressed pectin lyase in E. coli BL2I [DE3]. Thus pectin lyase secretion was achieved into the extracellular growth medium. $E$. coli cells harboring the recombinant plasmid heterologously express pectin lyase to around $22 \%$ of the total cellular proteins, as it was estimated by SDS-PAGE and image analysis. IPTG induces the heterologously expressed enzyme, which is initially distributed extracellularly (7 hour) and later on at the periplasmic ( 9 hours) or cytosolic fraction ( 20 hours). No pectin lyase activity was found in the membranes fraction and in the inclusion bodies. Encapsulation of the recombinant strains of $E$. coli in alginate or alginate/silica beads 1:5 showed that pectin lyase could degrade effectively its substrate, for at least ten operational cycles.

Conclusion: Secretion of an heterologously overexpressed pectin lyase in E. coli BL2I [DE3] was achieved in this study. For this purpose the signal peptide of $\alpha$-amylase from $B$. subtilis was fused to the $\mathrm{N}$-terminal domain of pectin lyase. Encapsulated E. coli BL2I [DE3] cells harboring PET29c/ exPNL were used successfully for pectin degradation up to ten operational cycles indicating that under special conditions this might have biotechnological implementations.

\section{Background}

Pectin lyase (PNL, EC 4.2.2.10) belongs to polysaccharide lyase family 1 and cleaves $\alpha-1,4$ bonds between galacturonic acid residues of pectin. The mode of PNL action is trans-elimination [1] with end-product oligosaccharides of 4-deoxy-6-methyl-alpha-D-galact-4-enuronosyl groups. Pectins are present in the primary cell wall and intracellular space of higher plants. The enzymic degrada- 


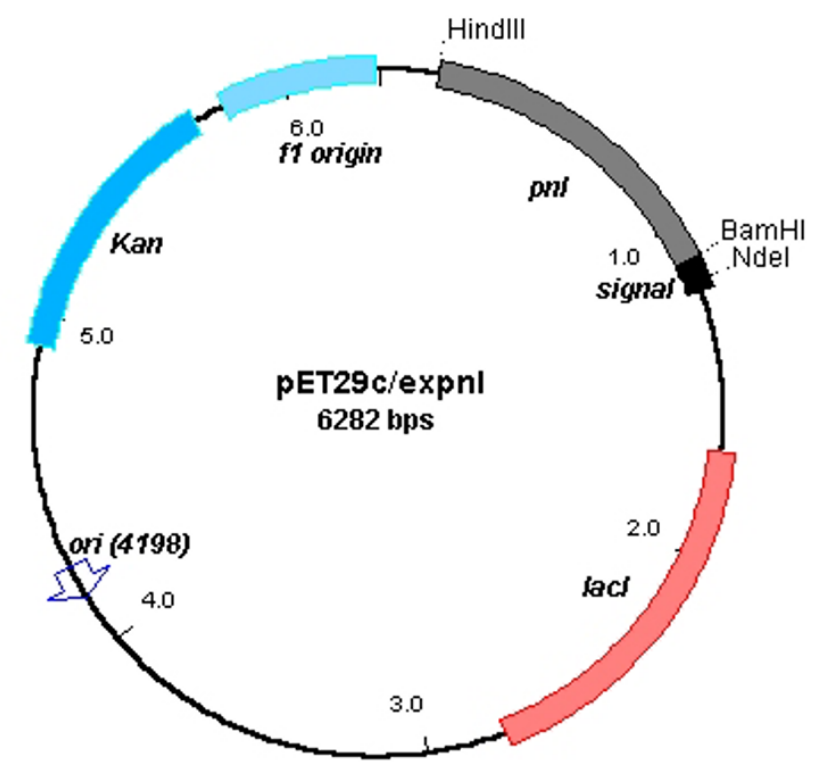

Figure I

Plasmid diagram of pET29c/expnl. Genes and major features of the plasmid are indicated by thick boxes. The restriction sites used in the construction are indicated as well.

tion of pectin is of great interest in food industry for fruit juice clarification, reduction of turbidity and increase of the amount of juice extracted from fruit pulp $[2,3]$. The enzymic degradation is also used in the textile industry in the processing of natural fibers [4]. Among the pectinolytic enzymes, pectin lyase is the only one known to degrade highly esterified pectin without the previous action of other enzymes [5].

Heterologous expression of pectin lyase gene ( $p n l)$ from Pseudomonas marginalis N6301 in E. coli BL21 [DE3] has previously been reported [6]. The enzyme was overproduced in the cytoplasm, bearing a 6-His-tag at the C-terminal, and it was purified close to homogeneity by affinity chromatography on a $\mathrm{Ni}^{++}$-NTA agarose column. Even though the heterologous expression of PNL was achieved in high yields there was a number of limitations compared to PNL production from its native source, the bacterium $P$. marginalis. It was necessary to disrupt bacterial cells to recover the enzyme with the proper protein folding.

Since secretion of recombinant proteins is preferred, many signal sequences derived from naturally occurring secretory proteins could be selected to support the efficient translocation of this heterologous polypeptide across the inner membrane, when fused to its amino termini [7]. Signal peptides usually consist of a positively charged amino-terminus (n-region, 1-5 residues in length), a central hydrophobic domain (h-region, 7-15 residues) and a neutral but polar carboxy-terminus domain (c-region, 3-7 residues). The c-region specifies the signal peptide cleavage site for specific signal peptidases whereas the other two domains are required for efficient translocation [8]. The length of signal peptides ranges from 22-32 amino acids. The majority of E. coli secreted proteins is either localized in the periplasm, or is associated with the inner or outer membranes [9]. Although recombinant proteins targeted to the periplasm remain to this cellular compartment, their release into the extracellular fluid may occur through non-specific leakage, or due to cell lysis $[10,11]$.

The signal peptide of $\alpha$-amylase from the gram-positive bacterium Bacillus subtilis cloned and excreted in E. coli, a Gram- bacterium, maps among the signal peptides of $E$. coli excreted proteins [12]. This Bacillus signal peptide can also achieve secretion in E. coli of the periplasmic space protein $\beta$-lactamase to the extracellular surroundings [13].

In this report, we studied the fusion of the 33-aminoacidsignal sequence of $B$. subtilis $\alpha$-amylase to the amino-terminal domain of pectin lyase and the secretion of the heterologous expressed pectin lyase. The transformed bacteria were further encapsulated in alginate beads and were tested successfully for pectin degradation.

\section{Results}

Construction of a himeric PNL carrying the signal peptide of B. subtilis $\alpha$-amylase

Isolated genomic DNA from B. subtilis was used as template for the amplification of the signal sequence of $\alpha$ amylase gene. Since the desired signal sequence of $\alpha$-amylase was very small, various primers were designed to anneal upstream and downstream of the promoter and the coding region of $\alpha$-amylase. After electrophoresis of PCR products on $1.5 \% \mathrm{w} / \mathrm{v}$ agarose gel the amplification fragment of the appropriate size was used as DNA template in a second PCR with primers only for the signal sequence of $\alpha$-amylase. Amplification of $\alpha$-amylase signal sequence was confirmed by agarose gel electrophoresis. Fragments were extracted from agarose gel with QIAEXII Gel Extraction Kit (Qiagen) and both signal sequence and pET29c/pnl were digested with NdeI and BamHI. After ligation of the digested plasmid and the insert, plasmid pET29c/expnl was generated (Fig. 1). The existence of $\alpha$ amylase's signal sequence in pET29c/expnl was confirmed by DNA sequencing.

\section{Overexpression of exPNL}

Cultures of E. coli BL21 [DE3] harboring pET29c/expnl were cultivated in LB medium and expnl gene was overex- 


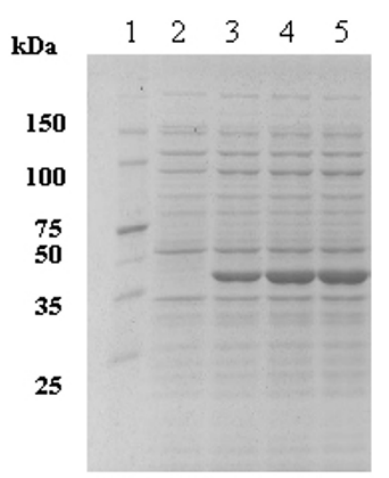

A

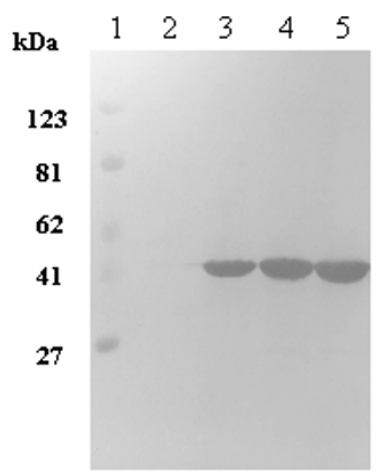

B

\section{Figure 2}

Overexpression of expnl gene. A: SDS-PAGE of $E$. coli exPNL total cells, lane I: pre-stained protein markers, lane 2: before the induction, lane 3: I h after the induction, lane 4: $2 \mathrm{~h}$ after the induction, lane 5: $3 \mathrm{~h}$ after the induction. Gel was stained with Coomassie Brilliant Blue R-250 B: transfer of proteins electrophoresed as in $A$ and immunostained with anti-His ( $1: 500)$

pressed after induction with IPTG. The total expressed proteins are shown at Fig. 2A. Overexpression of exPNL appears at lanes 3-5 of Fig. 2A. The presence of the recombinant exPNL was also confirmed by immunostaining of the same gel by anti-6-His (1:500 dilution), as shown at Fig. 2B lanes 3-5. The overproduction of exPNL was around $22 \%$ of the total amount of proteins, as estimated by the Gel-Pro Analyzer (version 3, Media Cybemetics, 1993-97) with the expected molecular mass of $39 \mathrm{kDa}$.

\section{Subcellular distribution of exPNL activity}

The appearance of pectin lyase in the extracellular fluid as well as at different subcellular fractions was studied. The presence of exPNL was estimated both by following its activity (Fig 3) and by SDS-PAGE (Fig. 4). In the periplasmic fraction exPNL activity was induced right after the addition of IPTG, with a peak at the first hour of induction. One hour later exPNL activity dramatically declined and then another peak of activity appeared 4-8 hours after IPTG addition. An increment of exPNL activity in the extracellular fluid was observed with a small delay comparing to that in the periplasm.

In the cytosolic fraction exPNL activity was increased 4 hours after induction with IPTG, whereas activity was not detectable in other fractions. Total protein $(10 \mu \mathrm{g})$ of each subcellular fraction and the extracellular medium, were electrophoresed and the proteins were stained with silver nitrate (Fig. 4). A large amount (12\%) of inactive exPNL

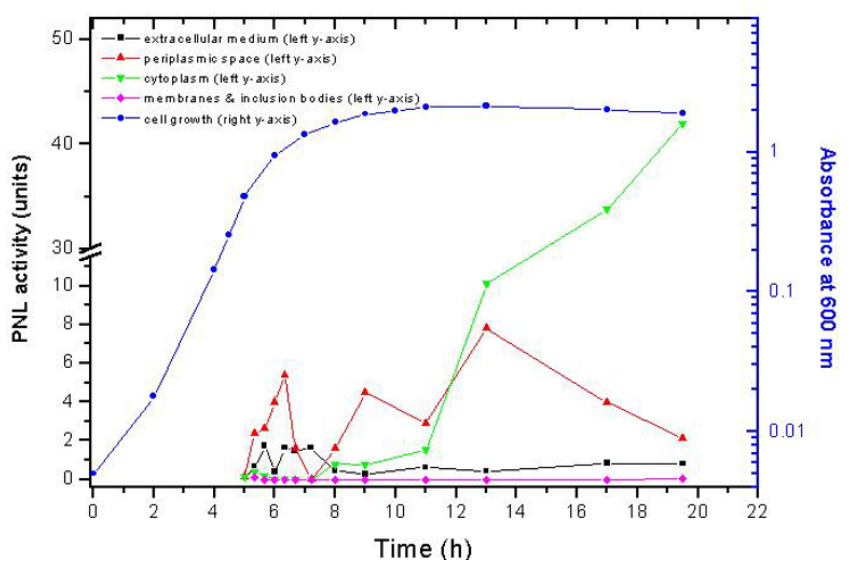

Figure 3

The appearance of exPNL activity in different fractions of $E$. coli, transformed with pET29c/expnl, during bacterial growth.

was present in the $100,000 \times \mathrm{g}$ pellet, as inclusion bodies, as it was judged by measuring the stained protein by the Gel-Pro Analyzer (Fig. 4D). Solubilization of inclusion bodies with $8 \mathrm{M}$ urea or $6 \mathrm{M}$ guanidine hydrochloride and renaturation by dialysis as described in Material and Methods resulted in an inactive enzyme. The extracellularly secreted exPNL was also immunostained with antiHis (1:500 dilution) and antiPNL (1:500 dilution) (Fig. $5)$. These results indicate that exPNL is overproduced by IPTG induction and migrates to the periplasmic fraction and is finally excreted to the extracellular medium.

\section{Cell encapsulation in alginate beads}

Sodium alginate is soluble in water and becomes a hydrogel in the presence of multivalent cations $\left(\mathrm{Ca}^{2+}, \mathrm{Ba}^{2+}\right.$, $\mathrm{Sr}^{2+}$ ). The resultant gel shows good permeability for small molecules [14]. In addition, the gelation of alginate can be achieved under mild conditions for immobilizing living cells. Thus, a variety of living cell phenotypes has been enclosed in such matrices [15-17]. To use more successfully the induced exPNL, transformed bacteria were encapsulated in alginate beads and used to degrade pectin for at least 10 operational cycles. Figure 6 shows the liberated exPNL activity in the extracellular fluid of the encapsulated bacteria at different operational cycle. After each operational cycle the encapsulated cells were allowed to rest for 1 hour in $\mathrm{LB}$ medium at $37^{\circ} \mathrm{C}$. The pattern of liberated exPNL activity in the extracellular fluid is very similar for the repeated batches, reaching maximal exPNL activity at 20 minutes of incubation. Even though the activity of exPNL during the first cycle was very small, in all other cycles it was very sufficient. As figure 6 shows a repetitive motif of increase and decrease of enzymic activity is observed that may reflect the cell growth inside the beads. Furthermore, the addition of toluene at concentrations of $0.2 \mathrm{mg} / \mathrm{ml}$ and $0.4 \mathrm{mg} / \mathrm{ml}$ in the reaction mixture 

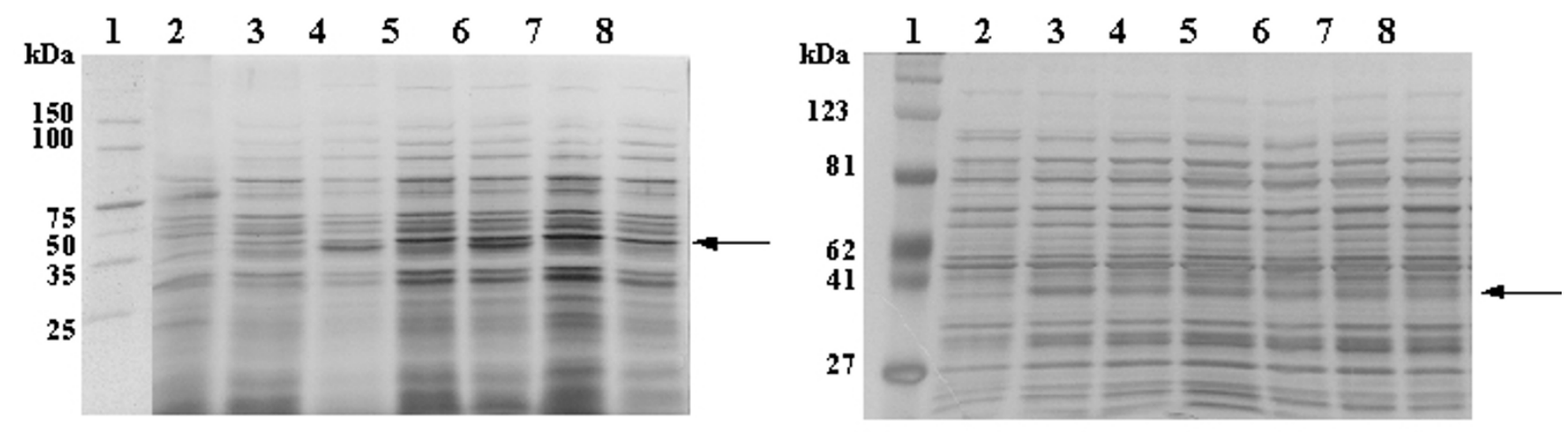

A

B

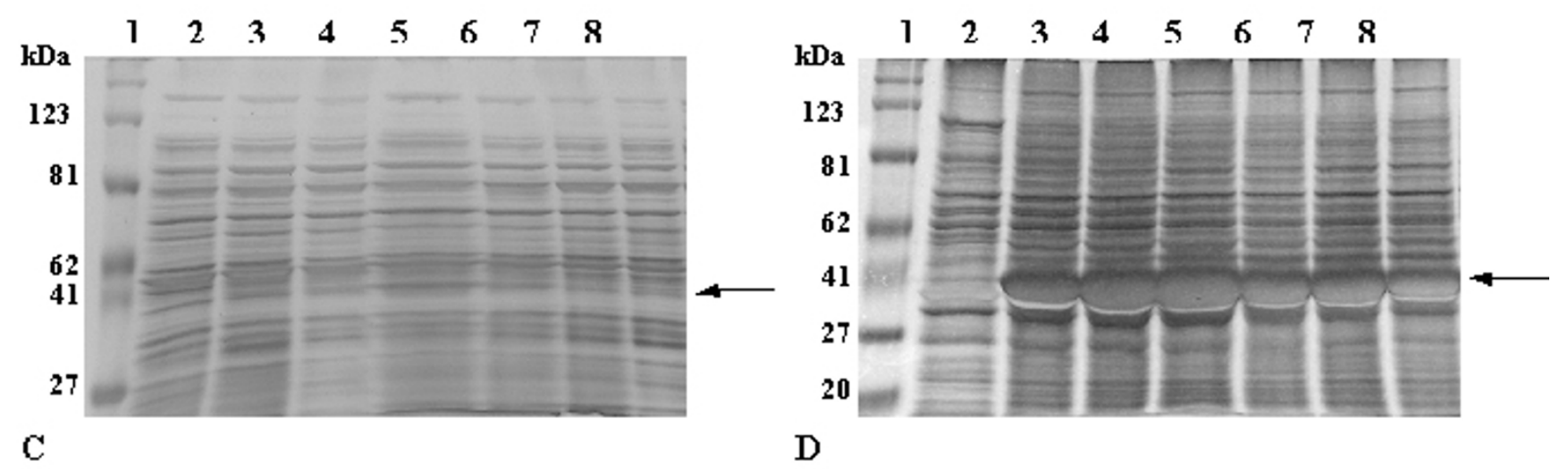

\section{Figure 4}

SDS-PAGE of the subcellular fractions of $E$. coli transformed with $P E T 29 c / e x p n l$, at different times of cell growth in presence of IPTG. A: extracellular medium, B: periplasmic space, C: cytoplasm, D: membranes and inclusion bodies - Lane I: protein markers, lane 2: before the induction with IPTG, lane 3: $20 \mathrm{~min}$ after the induction, lane 4: $40 \mathrm{~min}$ after the induction, lane 5: I $\mathrm{h}$ after the induction, lane 6: I h \& $40 \mathrm{~min}$ after the induction, lane 7: $3 \mathrm{~h}$ after the induction, lane 8: $6 \mathrm{~h}$ after the induction. Gels were stained with silver nitrate.

resulted, in both cases, in the increase of cell membrane permeability and finally in the 55\% increase of liberated exPNL by the encapsulated cells.

\section{Discussion}

There is a large number of reports on the secretory expression of recombinant proteins from E. coli $[9,18]$. Secreted polypeptides are synthesized as preproteins containing an amino-terminal signal sequence that is cleaved during the translocation process. This signal sequence is recognized and then cleaved by inner-membrane-associated signal peptidases. The secretion efficiency of these proteins is strongly dependent on the signal sequence used, the overall structure of the precursor protein and the processing of the signal peptide. Periplasmic production of recombinant proteins has several advantages with respect to cytoplasmic production, but frequently overproduced foreign proteins are not efficiently secreted to the periplasm in E. coli.
According to Sjöström et al. [12] the signal peptide of $B$. subtilis $\alpha$-amylase maps among the signal peptides of $E$. coli excreted proteins and when it was added to $\beta$-lactamase the protein was secreted to the periplasm [13]. It is also stated that the secretion mechanism of $B$. subtilis is similar to that of $E$. coli with minor differences with respect to substrate specificities of their signal peptidases, or in other proteins related to secretion. In particular, the signal peptide of $\alpha$-amylase has a sequence of Ala-Ala-SerAla recognized by type I signal peptidases, which are common in B. subtilis and E. coli [19]. These data lead us to the construction of plasmid pET29c/expnl from pET29c/pnl carrying the B. subtilis $\alpha$-amylase's signal sequence, introduced by NdeI and BamHI restriction sites (Fig. 1).

The recombinant PNL was secreted in the extracellular medium at around 30\% of the total activity at the early stage of induction and later on the activity accumulated in the cytoplasm. Those results suggested that either the bac- 


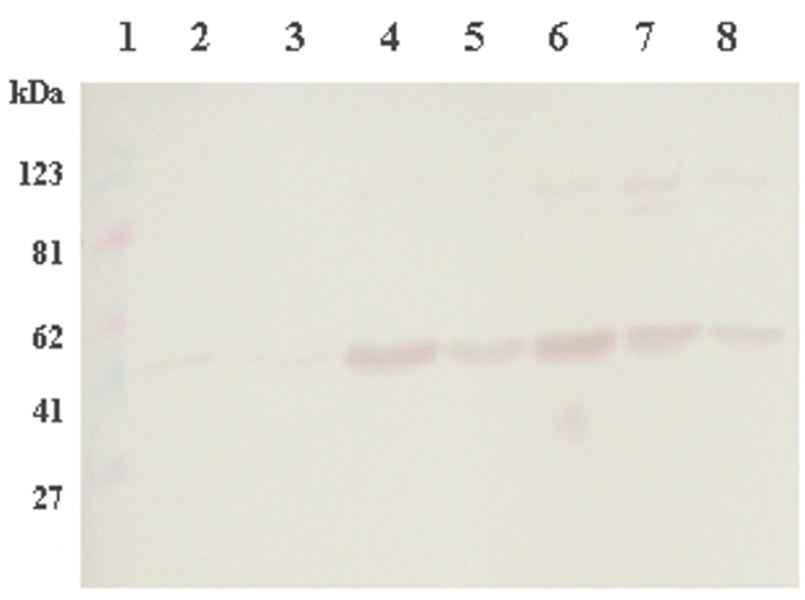

A

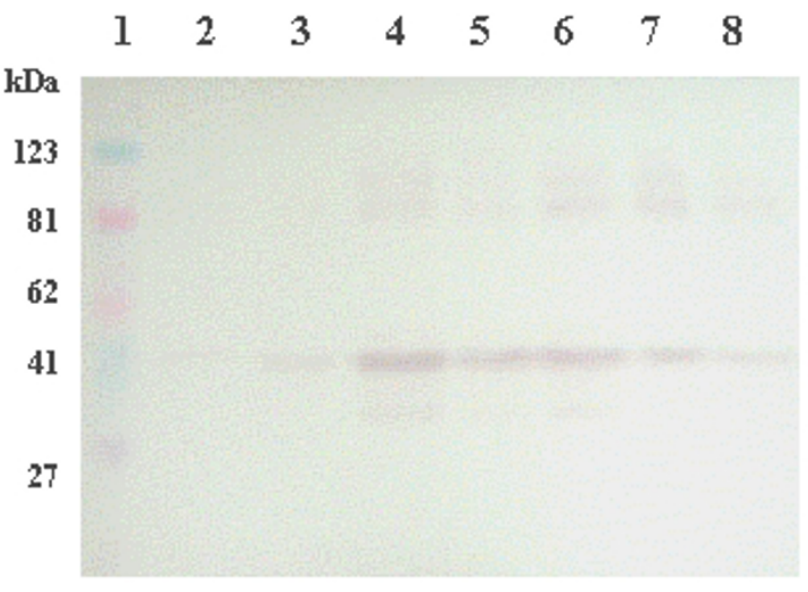

B

Figure 5

Total proteins electrophoresed as described at figure 5A, transferred and immunostained with anti-six-His (A) and anti-PNL (B).

terial secretory mechanism was not working effectively, or that the degradation of the protein was very fast.

Although the transformed bacteria were cultivated at low temperature, the overproduced exPNL was partially segregated as inclusion bodies. Recent reports presented that co-overproduction of SecB, DnaK-DnaJ and GroEL-GroES has met variable success and improved secretion for a number of heterologous proteins in E. coli [20-23]. Since the signal sequence influences secondary and tertiary structure formation of the secretory proteins, which in turn affect chaperone recognition, we would like to try several signal sequences and/or overproduce different chaperones to optimize the translocation of the overproduced exPNL in the near future. Even though exPNL was not secreted in high levels and the rate of hydrolysis was low, in our experiments we showed that transformed $E$. coli with pET29/expnl encapsulated in alginate beads or alginate/silica gel 1:5 can be used for pectin degradation effectively, for at least ten operational cycles.

So far the commercial pectolytic preparations that are used in food processing industries, are crude multienzyme preparations from Aspergillus niger and contain hemicellulase, cellulase, xylanase, pectin esterase, polygalacturonase and pectin lyase [24]. Although pectolytic enzymes are widely used for industrial purposes, little research has been carried out on pectolytic enzymes immobilized in solid matrices and even less on cell encap- sulation. Previously pectin lyase has been immobilized on DEAE-cellulose, on porous glass [25] and recently on nylon, with no loss of enzymic activity after 12 cycles of operation [26]. Our results of using encapsulated bacterial cells capable of secreting pectin lyase appear to be of potential interest for an industrial application.

\section{Conclusion}

The aim of this study was the secretion of an heterologously overexpressed pectin lyase in E. coli BL21 [DE3]. For this purpose, the signal peptide of $\alpha$-amylase from $B$. subtilis was fused to the N-terminal domain of pectin lyase that had been previously [6] cloned and overexpressed in E. coli BL21 [DE3]. Secretion into the extracellular medium was observed right after IPTG induction but then the fusion protein was accumulated in the periplasm and cytoplasm. Encapsulated E. coli BL21 cells harboring pET29c/exPNL in alginate beads, capable of secreting pectin lyase were used successfully for pectin degradation up to ten operational cycles, providing expenditure for future biotechnological applications.

\section{Materials and methods \\ Material}

All chemical compounds were purchased from SIGMA, Fluka, Baker and BDH Chemicals. Restriction enzymes, Taq polymerase and other reagents needed for molecular biology experiments were purchased from New England Biolabs. 


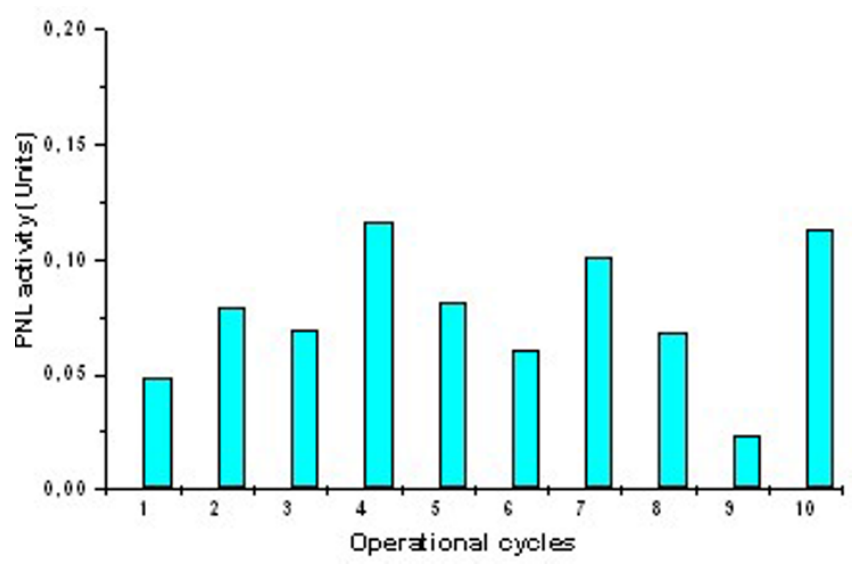

Figure 6

Enzymic degradation of pectin by encapsulated in alginate beads $E$. coli cells transformed with pET29c/expnl. Each column represents pectin lyase activity measured at 20 min of incubation.

\section{Isolation of DNA}

Genomic DNA from B. subtilis was isolated according to Saito and Miura as modified by Gay [27,28]. Plasmid DNA was extracted by alkaline lysis [29].

\section{Construction of pET29c/expnl containing $\alpha$-amylase's signal sequence}

We have recently reported that $p n l$ gene of $P$. marginalis was amplified by PCR and cloned into plasmid pET29c using BamHI and HindIII restriction sites [6]. In this paper plasmid pET29c/expnl is constructed from pET29c/ pnl and B. subtilis $\alpha$-amylase's signal sequence [30] to secrete pectin lyase. Larger fragments containing $\alpha$-amylase's signal sequence were amplified by PCR using B. subtilis genomic DNA as the template and proper oligonucleotides. The reaction was performed as follows: $50 \mu \mathrm{l}$ reaction volume was prepared to contain 2 units of Taq polymerase, $5 \mu \mathrm{l}$ of polymerase buffer, $200 \mu \mathrm{M}$ of each dNTP, $0.13 \mu \mathrm{g} / \mu \mathrm{l}$ of each primer and $1 \mathrm{ng}$ of template DNA. The reaction mixture was cycled 30 times using the following conditions: $92^{\circ} \mathrm{C}$ for $1 \mathrm{~min}, 54^{\circ} \mathrm{C}$ for $30 \mathrm{sec}, 72^{\circ} \mathrm{C}$ for $50 \mathrm{sec}$ and another $5 \mathrm{~min}$ at $72^{\circ} \mathrm{C}$ at the end of the cycles. The amplification products were electrophoresed in $1.5 \% \mathrm{w} / \mathrm{v}$ agarose gel and products of right size were used as the template DNA in a second PCR, where primers specific for $\alpha$-amylase's signal sequence and with NdeI and BamHI restriction sites were used (forward: 5'-GGAATTCCATATGTTTGCAAAACGA-3', reverse: 5'-CGCGGATCCTACTCGCAGCC-3'). The reaction mixture and the conditions for PCR were the same as described above. The PCR product was electrophoresed in $1.5 \% \mathrm{w} / \mathrm{v}$ agarose gel and then was cut and extracted from the gel using the Qiagen gel extraction kit. The 99 bp NdeI-BamHI PCR fragment was introduced into the NdeI-
BamHI fragment of pET29c/pnl resulting in pET29c/expnl plasmid. E. coli BL21 [DE3] competent cells were prepared according to Sambrook et al. [29] and transformed with pET29c/expnl.

\section{Microorganisms and growth conditions}

The recombinant strains of $E$. coli BL21 [DE3] with the constructed plasmid pET29c/expnl were grown at $37^{\circ} \mathrm{C}$, in LB medium containing kanamycin $(50 \mu \mathrm{g} / \mathrm{ml})$ with vigorous agitation. When cells reached an optical density of 0.6 at $600 \mathrm{~nm}$, IPTG $(1 \mathrm{mM})$ was added and the cultures were incubated at $24^{\circ} \mathrm{C}$, for 3 hours. B. subtilis was grown at $37^{\circ} \mathrm{C}$, in $\mathrm{LB}$ medium with vigorous agitation.

Preparation of cell extracts and subcellular fractionation Recombinant strains of E. coli BL21 [DE3] harboring pET29c/expnl, grown as described above, were harvested by centrifugation at $3,000 \times \mathrm{g}$ for $15 \mathrm{~min}$ at $4^{\circ} \mathrm{C}$. The cell pellet was washed twice with PBS and suspended in $5 \times \mathrm{ml}$ of $0.5 \mathrm{M}$ sucrose, $250 \mathrm{mM}$ EDTA and $2 \mathrm{mg} / \mathrm{ml}$ lysozyme. The suspension was incubated on ice for $30 \mathrm{~min}$ and centrifuged at $20,000 \times \mathrm{g}$ for $15 \mathrm{~min}$. The supernatant was kept/saved as the periplasmic fraction. The remaining pellet was suspended in $50 \mathrm{mM}$ Tris-HCI ( $\mathrm{pH} 7.5), 2.5 \mathrm{mM}$ EDTA and then sonicated ( 5 times $\times 30 \mathrm{sec}, 0.5$ cycle, $50 \%$ amplitude - UP200 s dr. hielscher, GmbH). After addition of $\mathrm{MgSO}_{4}$ to a final concentration $40 \mathrm{mM}$, the mixture was centrifuged at $100,000 \times \mathrm{g}$ for $40 \mathrm{~min}$. The $100,000 \times \mathrm{g}$ supernatant was kept as the cytoplasmic fraction and the $100,000 \times \mathrm{g}$ pellet as the membrane fraction with the inclusion bodies. The pellet $100,000 \times \mathrm{g}$ was suspended in $1 \mathrm{ml}$ of $50 \mathrm{mM}$ Tris-HCl buffer $\mathrm{pH} 7.5$ [31].

\section{Enzyme assay}

PNL activity was determined spectrophotometrically by monitoring the increase in absorbance at $235 \mathrm{~nm}$ of a solution containing $0.1 \% \mathrm{w} / \mathrm{v}$ pectin (Sigma, P-9135) in $50 \mathrm{mM}$ citrate/phosphate buffer $\mathrm{pH} 6.5$ at $37^{\circ} \mathrm{C}$. The increase in absorbance was measured after 20 minutes of incubation. One unit of PNL activity was defined as the nmoles of unsaturated oligogalacturonides produced per minute, under the above-specified condition [32]. Specific activity of PNL was defined as the ratio of PNL units per mg of protein extract. The absorption coefficient of unsaturated oligogalacturonides is $5500 \mathrm{M}^{-1} \mathrm{~cm}^{-1}$.

\section{Electrophoresis and immunoblotting}

SDS electrophoresis was performed in $10 \% \mathrm{w} / \mathrm{v}$ polyacrylamide gels containing $0.1 \% \mathrm{w} / \mathrm{v}$ SDS as described by Laemmli [33]. Protein content was determined by the method of Bradford [34]. Gels were stained either with Coomassie Brilliant Blue R250 [35] or with silver nitrate [36]. Proteins were transferred to nitrocellulose membranes following the method of Towbin et al. [37] and immunostained as described [38]. 


\section{Solubilization and renaturation of inclusion bodies}

The $100,000 \times \mathrm{g}$ pellet containing the inclusion bodies was either dissolved in 10 fold volume of $50 \mathrm{mM}$ Tris- $\mathrm{HCl}$ $\mathrm{pH}$ 8.0, $5 \mathrm{mM} \mathrm{NaCl}, 5 \mathrm{mM} \mathrm{MgCl}$, $2.5 \mathrm{mM} \beta-\mathrm{MSH}, 0.1 \%$ w/v Tween 20 (DR, Denaturation - Renaturation buffer) containing $8 \mathrm{M}$ urea, or in $50 \mathrm{mM}$ Tris- $\mathrm{HCl} \mathrm{pH} \mathrm{8.0,6} \mathrm{M}$ guanidine hydrochloride, $1 \mathrm{mM}$ DTT to a final concentration of $1 \mathrm{mg} / \mathrm{ml}$. Solubilization of inclusion bodies was proceed at room temperature for 1 hour. In the first case the mixture was centrifuged at $100,000 \times \mathrm{g}$ for $20 \mathrm{~min}$ at $4^{\circ} \mathrm{C}$ and then the $100,000 \times \mathrm{g}$ supernate was dialyzed gradually against DR buffer containing lower concentrations of urea $(6,4,2,1 \mathrm{mM}$ urea) and finally overnight just in DR buffer. In the second case the mixture was diluted tenfold with the same buffer and dialyzed overnight against a 100 fold volume of $50 \mathrm{mM}$ Tris- $\mathrm{HCl} \mathrm{pH}$ 8.0, $150 \mathrm{mM} \mathrm{NaCl}, 1 \mathrm{mM}$ DTT and 5\% glycerol. Dialysis was followed by centrifugation at 50,000 $\times \mathrm{g}$ for $30 \mathrm{~min}$ at $4^{\circ} \mathrm{C}$ and enzyme activity was determined. In all steps 1 mM PMSF was added.

\section{Formation of alginate beads}

After 2 hours of induction with IPTG, cells were harvested at $3000 \times \mathrm{g}$ for $20 \mathrm{~min}$ and mixed with sterile water $(300$ $\mathrm{mg}$ cells $/ \mathrm{ml})$. Sodium alginate solution $(2 \% \mathrm{v} / \mathrm{v})$ was mixed with the above cell suspension at a volumetric ratio of 9:1 and the mixture was dropped with an insulin syringe into a gently stirred $1 \% \mathrm{w} / \mathrm{v}$ solution of $\mathrm{BaCl}_{2}$ at a volumetric ratio of 1:50. A spontaneous cross-linking reaction produced spherical hydrogel beads of barium alginate, which remained for 30 minutes at $4{ }^{\circ} \mathrm{C}$ in order to stabilize the formed network. After stabilization, the beads were washed with $0.9 \% \mathrm{v} / \mathrm{v} \mathrm{NaCl}$ (twice) and used immediately. All solutions that were used are sterile.

\section{Pectin hydrolysis by the transformed bacteria encapsulated in alginate beads}

Pectin hydrolysis was performed in conical flasks at $37^{\circ} \mathrm{C}$ under gentle stirring and each operational cycle lasts for 1 $\mathrm{h}$. The substrate used was the same as for enzyme assay with the addition of LB solution (25:1 final concentration) and $\mathrm{BaCl}_{2}$ at a final concentration of $0.005 \% \mathrm{v} / \mathrm{v}$ in order to preserve cell viability and network stability. At the end of each cycle, beads were washed with $0.9 \% \mathrm{v} / \mathrm{v} \mathrm{NaCl}$ (twice) and placed with fresh LB solution at room temperature under gentle shaking for $1 \mathrm{~h}$. This procedure was repeated after each operational cycle.

\section{Abbreviations}

PNL, pectin lyase; exPNL, extracellular pectin lyase; IPTG, isopropylthiogalactoside

\section{Authors' contributions}

All authors contributed equally in this paper.

\section{References}

I. Linhardt RJ, Galliher PM, Cooney CL: Polysaccharide lyases. Appl Biochem Biotechnol 1986, I 2: I35-I76.

2. Gupta MN, Guogiang D, Mattiasson B: Purification of endo-polygalacturonase by affinity precipitation using alginate. Biotechnol Appl Biochem 1993, 18:321-327.

3. Pilnik W, Rombouts FM: Polysaccharides and food processing. Carbohydr Res 1985, 142:93-105.

4. Sharma HSS: Enzymatic degradation of residual non cellulosic polysaccharides present on dew-retted flax fibres. Appl Microbiol Biotechnol 1987, 26:358-362.

5. Alana A, Alkorta I, Dominguez JB, Llama MJ, Serra JL: Pectin lyase activity in a Penicillium italicum strain. Appl Environ Microbiol 1990, 56:3755-3759.

6. Papi RM, Kyriakidis DA: Overexpression of the pectin lyase of Pseudomonas marginalis in Escherichia coli and purification of the active enzyme. Biotechnol Appl Biochem 2003, 37:187-194.

7. Baneyx F: Recombinant protein expression in Escherichia coli. Curr Opin Biotechnol 1999, 10:4 II-42I.

8. Von Heijne G: How signal sequences maintain cleavage specificity. J Mol Biol I 984, I 73:243-25I.

9. Georgiou G, Segatori L: Preparative expression of secreted proteins in bacteria: status report and future prospects. Curr Opin Biotechnol 2005, 16: I-8.

10. Lazzaroni JC, Portalier RC: Genetic and biochemical characterization of periplasmic leaky mutants of Escherichia coli K-I 2. J Bacteriol 1981, | 45:1351-1358.

II. Hewinson RG, Russell WP: Processing and secretion by Escherichia coli of a recombinant form of the immunogenic protein MPB70 of Mycobacterium bovis. J Gen Microbiol 1993, I39: 1253-1259.

12. Sjöström M, Wold S, Wieslander A, Rilfors L: Signal peptide amino acid sequences in Escherichia coli contain information related to final protein localization. A multivariate data analysis. EMBO J 1987, 6:823-831.

13. Nakazawa K, Takano T, Sohma A, Yamane K: Secretion activities of Bacillus subtilis alpha-amylase signal peptides of different lengths in Escherichia coli cells. Biochem Biophys Res Commun 1986, I34:624-631.

14. Li RH, Altreuter DH, Gentile FT: Transport characterization of hydrogen matrices for cell-encapsulation. Biotechnol Bioeng 1996, 50:365-373.

15. Willaert RG, Baron GV: Gel entrapment and microencapsulation: methods, applications and engineering principles. $\operatorname{Rev}$ Chem Eng 1996, I 2:85-I I5.

16. Smidsrod $O$, Skjak-Braek G: Alginate as immobilization matrix for cells. Trends Biotechnol 1990, 8:71-78.

17. Sakai S, Ono T, ljima H, Kawakami K: Behavior of enclosed soland gel-alginates in vivo. Biochem Engin J 2004, 22:19-24.

18. Wan EW-M, Baneyx F: TolAIII co-overexpression facilitates the recovery of periplasmic recombinant proteins into the growth medium of Escherichia coli. Protein Expres Purif 1998, 14:13-22.

19. Tuteja R: Type I signal peptidase: An overview. Arch Biochem \& Biophys 2005, 44I: I07-III.

20. Bergés $H$, Joseph-Liauzun $E$, Fayet $O$ : Combined effects of the signal sequence and the major chaperone proteins on the export of human cytokines in Escherichia coli. Appl Environ Microbiol 1996, 62:55-60.

21. Thomas JG, Ayling A, Baneyx F: Molecular chaperones, folding catalysts and the recovery of active recombinant proteins from Escherichia coli: to fold or to refold. Appl Biochem Biotechnol 1997, 66:197-238.

22. Pérez-Pérez J, Martinez-Caja C, Barbero JL, Gutiérrez J: DnaK/DnaJ supplementation improves the periplasmic production of human granulocyte-colony stimulating factor in Escherichia coli. Biochem Biophys Res Commun 1995, 2 1 0:524-529.

23. Hayhurst A, Harris WJ: Escherichia coli Skp shaperone coexpression improves solubility and phage display of single chain antibody fragments. Protein Expr Purif 1999, I 5:336-343.

24. Naidu GSN, Panda T: Production of pectolytic enzymes - a review. Bioprocess Engineering 1998, 19:355-361.

25. Hanisch WH, Rickard PAD, Nyo S: Poly(methoxygalacturonide) lyase immobilized via titanium onto solid supports. Biotechnol Bioeng 1978, 20:95-106. 
26. Alkorta I, Garbisu C, Llama ML, Serra JL: Immobilization of pectin lyase from Penicillium italicum by covalent binding to nylon. Enzyme Microb Technol 1996, 18:141-146.

27. Saito H, Miura K: Preparation of transforming deoxyribonucleic acid by phenol treatment. Biochim Biophys Acta 1963, 72:619-629.

28. Gay NJ: Construction and characterization of an Escherichia coli strain with a uncl mutation. J Bacteriol 1984, I 58:820-825.

29. Sambrook J, Fritsch EF, Maniatis T: Molecular cloning. A laboratory manual. Cold Spring Harbor Laboratory Press: New York; 1989.

30. Yang M, Galizzi A, Henner D: Nucleotide sequence of the amylase gene from Bacillus subtilis. Nucleic Acids Res 1983, I I:237-249.

31. Yamane K, Mizushima S: Introduction of basic amino acid residues after the signal peptide inhibits protein translocation across the cytoplasmic membrane of Escherichia coli. J Biol Chem 1988, 263:19690-19696.

32. Albersheim P, Killias U: Studies relating to the purification and properties of pectin transeliminase. Arch Biochem Biophys 1962, 97:107-115.

33. Laemmli UK: Cleavage of structural proteins during the assembly of the head of bacteriophage T4. Nature 1970, 227:680-685.

34. Bradford MM: A rapid and sensitive method for the quantitation of microgram quantities of proteins utilizing the principle of protein-dye binding. Anal Biochem 1976, 72:248-254.

35. Hames BD, Rickwood D: Gel Electrophoresis. A practical approach. IRL Press: Oxford-Washington DC; 1985.

36. Blum H, Beir H, Gross HJ: Improved silver staining of plant proteins, RNA and DNA in polyacrylamide gels. Electrophoresis 1987, 8:93-98.

37. Towbin H, Staehelin T, Gordon J: Electrophoretic transfer of proteins from polyacrylamide gels to nitrocellulose sheets: procedure and some applications. Proc Natl Acad Sci (USA) 1979, 76:4350-4354.

38. Blake MS, Johnston KH, Russels-Jones GJ, Gotschlich EC: A rapid, sensitive method for the detection of alkaline phosphataseconjugated anti-antibody on western blots. Anal Biochem 1984, 136: 175-179.

Publish with Bio Med Central and every scientist can read your work free of charge

"BioMed Central will be the most significant development for disseminating the results of biomedical research in our lifetime. "

Sir Paul Nurse, Cancer Research UK

Your research papers will be:

- available free of charge to the entire biomedical community

- peer reviewed and published immediately upon acceptance

- cited in PubMed and archived on PubMed Central

- yours - you keep the copyright 